Summer 2014

\title{
Protecting the Home Turf: National Bar Associations and the Foreign Lawyer
}

Brendan K. Smith

Indiana University Maurer School of Law, smith821@indiana.edu

Follow this and additional works at: https://www.repository.law.indiana.edu/ijgls

Part of the International Law Commons, and the Legal Profession Commons

\section{Recommended Citation}

Smith, Brendan K. (2014) "Protecting the Home Turf: National Bar Associations and the Foreign Lawyer," Indiana Journal of Global Legal Studies: Vol. 21 : Iss. 2 , Article 11.

Available at: https://www.repository.law.indiana.edu/ijgls/vol21/iss2/11

This Note is brought to you for free and open access by the Law School Journals at Digital Repository @ Maurer Law. It has been accepted for inclusion in Indiana Journal of Global Legal Studies by an authorized editor of Digital Repository@Maurer Law. For more information, please contactrvaughan@indiana.edu.

\section{$\Psi$}

JEROME HALL LAW LIBRARY

INDIANA UNIVERSITY

Maurer School of Law
Bloomington 


\title{
Protecting the Home Turf: National Bar Associations and the Foreign Lawyer
}

\author{
BRENDAN K. SMITH*
}

\begin{abstract}
This note addresses the issues raised by domestic laws and bar associations limiting the practice of foreign lawyers. It looks at how the increase in globalization has led different countries to take different approaches toward dealing with these foreign lawyers. There are complex and varying reasons for how a country approaches foreign lawyers, as is demonstrated particularly through the actions of Brazil, India, and Japan. Also, it appears that emerging, but not as of yet established, global economic powers have decided it is in their interest to severely restrict the activity of foreign lawyers. The note suggests that these emerging powers should take the approach that Japan has taken and incrementally liberalize their rules regarding foreign lawyers and law firms. Despite the increased liberalization demonstrated by Japan and some states in the United States, there is little indication that emerging powers will lift their protectionist measures anytime soon.
\end{abstract}

\section{INTRODUCTION}

Globalization is here to stay, and professionals are not immune to its effects. Whether globalization is good or bad is up for debate, ${ }^{1}$ but the fact remains that it is a part of life for modern professionals. ${ }^{2}$ Much of this has to do with the fact that travel among countries has proliferated in recent years and that technology allows people throughout the world

* Notes Editor, Indiana Journal of Global Legal Studies; J.D., 2014, Indiana University Maurer School of Law. Thank you to the Indiana Journal of Global Legal Studies for this opportunity and greater thanks to everyone who helped with the note.

1. See Cornelia Nistor, Positive and Negative Effects of Globalization, 1 ANNALS U. BUCHAREST (ECON. \& ADMIN.) 152 (2007).

2. See Denise Grady, Foreign-Born Doctors Give Equal Care in U.S., N.Y. TIMES, Aug. 3, 2010, http://www.nytimes.com/2010/08/03/health/03doctors.html?_r=0; Matt McAllester, America is Stealing the World's Doctors, N.Y. TIMES, Mar. 7, 2012, http://www.nytimes.com/ 2012/03/11/magazine/america-is-stealing-foreign-doctors.html? pagewanted=all.

Indiana Journal of Global Legal Studies Vol. 21 \#2 (Summer 2014)

(C) Indiana University Maurer School of Law 
to remain in quick, constant contact with each other. Due to the increased mobility of people in the world, particularly modern professionals, countries must determine whether they are open to globalization or prefer to shutter themselves away from its ever increasing influence. ${ }^{3}$

While some professional degrees are easily transferrable,${ }^{4}$ lawyers and those holding law degrees are in a fairly unique position due to the fact that most lawyers' jobs are entirely dependent on the law of the country and, often times, the specific jurisdiction in which they practice. This unique position of the legal professional has led some national and local bar associations to introduce rules that restrict the practice of foreign lawyers. ${ }^{5}$ While this protectionism is not necessarily a bad thing, as domestic lawyers educated within a country are often better suited to handle matters dealing with national law, it also produces undesirable side effects. Furthermore, globalization does not show significant signs of stopping or even slowing down. Protectionist measures may simply be forestalling the inevitable when it is more valuable to a country to get ahead of the curve and bring in the most qualified lawyers possible, regardless of where they are educated.

This note addresses the issue presented by the globalization of the legal profession and how various countries have reacted to this movement. Within the United States, there have been varying approaches that will be addressed, but some of the states that are most influential globally, such as New York, have relaxed their rules regarding foreign lawyers and the practice of local law, which may be an indication of where things are moving. ${ }^{6}$ The first section of this note addresses how various countries, including the United States, Brazil, India, and the United Kingdom, have confronted the issue of foreign lawyers working within their jurisdictions. While some of these countries share a common law heritage, it does not necessarily mean they allow lawyers educated in foreign common law countries to practice local law. The second section discusses the concerns raised by the protectionist measures put in place to regulate foreign lawyers. ${ }^{7}$ The third section then explores whether there is a way to resolve the issue of

3. See Anna Stolley Persky, Despite Globalization, Lawyers Find New Barriers to Practicing Abroad, ABA J., Nov. 2011, available at http://www.abajournal.com/ magazine/article/the_new_world_despite_globalization_lawyers_find_new_barriers_to_pra cticing/

4. See McAllester, supra note 2.

5. See Perskey, supra note 3.

6. See Taking the Bar as a Foreign Lawyer, INT'L STUDENT, http://www.internationalstudent.com/study-law/taking-bar-foreign-lawyer.shtml (last visited July 27, 2012).

7. See Perskey, supra note 3. 
the foreign lawyer practicing local law. This section also discusses whether the protectionist measures are merely an attempt to forestall the inevitability of the globalization of the legal profession.

\section{VARYING APPROACHES TO THE FOREIGN LAWYER}

Whether a particular bar association likes it, foreign lawyers exist and their role will continue to expand as globalization continues to expand. In the last fifteen or so years, tertiary education around the globe has expanded drastically. ${ }^{8}$ As law school is included in the increase of tertiary education, more people are receiving legal educations globally, even if the recent economic downturn in the United States has caused fewer people to attend law school. ${ }^{9}$ There is no reason to think that, as the global economy rebounds from recent economic issues felt worldwide, fewer people will attend law school. Rather, it is likely that there will be an increasing number of lawyers and that, given the ease of mobility in the global age, lawyers may begin searching for jobs in countries where they otherwise may not have in the past. ${ }^{10}$ Many countries have already taken steps to address the issue of foreign lawyers in their country. In the following subsections, I will discuss the approaches taken by the United States, Brazil, India, Japan, and the United Kingdom.

\section{A. United States}

As anyone familiar with the legal system in the United States is aware, licensing is done at the state level, as opposed to the national level." Given the federal structure of the United States, this makes sense, and it also allows the various state bar associations to develop different ways of addressing a concern. While some states are certainly more susceptible to the influx of foreign lawyers, each will likely feel the effects of globalization, and each state bar association must address this issue. Already, there are varying approaches taken among the states, and they could not be more different. ${ }^{12}$

8. Caroline Macready \& Clive Tucker, Who Goes Where and Why? 10 (2011).

9. See Jordan Weissmann, The Wrong People Have Stopped Applying to Law School, THE ATLANTIC (Apr. 10, 2012, 10:37 AM), http://www.theatlantic.com/business/archive/ 2012/04/the-wrong-people-have-stopped-applying-to-law-school/255685/.

10. See Perskey, supra note 3.

11. See Bar Admissions Basic Overview, LSAC, http://www.lsac.org/jd.think.admissionto-bar.asp (last visited Mar. 29, 2014).

12. See Taking the Bar as a Foreign Lawyer, supra note 6. 
At the very protectionist end of the spectrum, some states make it extremely difficult for a foreign lawyer to practice law in their jurisdictions. While these states do not have rules that are openly hostile to a foreign lawyer, their rules essentially send the message that they want lawyers educated in the United States to practice within their borders. Twenty-three states have rules that require a lawyer to be educated at an American Bar Association (ABA) accredited law school to be licensed to practice within their jurisdictions. ${ }^{13}$ As of now, the ABA has not accredited any law schools outside of the United States, ${ }^{14}$ so a lawyer directly licensed by one of those states must attend law school in the United States.

The only feasible way a foreign-educated lawyer could become licensed in one of those twenty-three states is through reciprocity. Most states allow individuals who are licensed in one state to move to another and become licensed. ${ }^{15}$ While this certainly presents an opportunity for foreign lawyers who want to practice in a state that will not allow them to be directly licensed, it is not always simple. Reciprocity among states often involves practicing or being licensed in a state for a period of years before reciprocity kicks in. ${ }^{16}$ Furthermore, as will be seen, there are only a limited number of states that directly license foreign lawyers, ${ }^{17}$ so the opportunities are narrow to begin with.

There are currently five states that will allow a foreign lawyer to become licensed without having attended an ABA accredited law school. ${ }^{18}$ These states are: California, New York, Alabama, New Hampshire, and Virginia. ${ }^{19}$ As evidenced by New York, California, and Virginia, some of the areas most affected by globalization have determined it is in their interest to allow foreign-educated lawyers to practice local law. New York City is the largest legal market in the United States, and with the large international presence in the city, which includes the United Nation headquarters, foreign lawyers will be attracted to practice in New York. Even though the number of legal jobs has dwindled, New York has avoided the protectionist temptation that many other states have, which demonstrates that allowing foreigneducated lawyers, and thus global competition for jobs, most likely creates a stronger legal environment.

13. Id.

14. Id.

15. See Nikki LaCrosse, Guidelines on Reciprocity or "Admission on Motion" Among the States as per American Bar Association, LAWCROSSING.COM, http://www.lawcrossing.com/ article/1084/Reciprocity-Laws-Amont-the-States/\# (last visited Dec. 1, 2012).

16. Id.

17. Taking the Bar as a Foreign Lawyer, supra note 6.

18. Id.

19. $I d$. 
Neither of these approaches taken by states clearly presents the "right" answer to handling foreign-educated lawyers. However, given that some of the largest legal markets in the United States and places most affected by globalization have determined it is appropriate to directly license foreign-educated lawyers, those states may represent the inevitable direction that the other states will take as globalization increases and touches more areas of the United States. As will be seen, the approaches taken by the different factions of states also represent approaches taken by other countries, though those countries rarely include the backdoor option of reciprocity that exists in the United States.

\section{B. Brazil}

Brazil is one of the fastest growing economies in the world, ${ }^{20}$ and with that comes an increased interest from professionals in moving to Brazil. ${ }^{21}$ In recent years, foreign law firms, particularly U.S. law firms, ${ }^{22}$ have taken notice of Brazil's growing stature in the world economy and have made efforts to establish offices within Brazil. The effort to break into Brazil's legal market has not been appreciated much by the Ordem dos Advogados (OAB), which is the Brazilian equivalent of the bar association and is responsible for legal licensing within Brazil. As will be discussed later, foreign-educated lawyers, and by extension foreign law firms, are not allowed to practice local law, so they are limited to consulting and international law practice. ${ }^{23} \mathrm{As}$ a result, many foreign law firms have resorted to creating partnerships with local Brazilian law firms to carry out their consulting. ${ }^{24}$ However, just as the influx of foreign law firms into Brazil has increased in recent years, so too has

20. See Juan Forero, Brazil Quickly Becoming a Player in the Global Economy, WASH. Post (Sept. 21, 1998), www.washingtonpost.com/wp-dyn/content/article/2010/09/20/ AR2010092003685.html; Oliver Stuenkel, As Brazil Turns into 6th Largest Economy, Unfamiliar Challenges Loom, PosT-W. WORLD (Oct.15, 2012), http:/www.postwesternworld.com/2011/12/30/as-brazil-turns-into-6th-largest-economyunfamiliar-challenges-loom/.

21. See Oliver Stuenkel, How Immigration Will Change Brazil, PosT-W. WorLD (Oct. 15, 2012), http://www.postwesternworld.com/2011/04/10/how-immigration-will-change-brazil/.

22. See Brazil Nuts: Why Law Firms are Flocking to Sao Paulo, HiLdebrant INST. (Oct. 27 2011), http:/hildebrandtblog.com/2011/10/27/brazil-nuts-why-law-firms-areflocking-to-sao-paulo/.

23. See Jose Mauricia Machado, Foreign Law Firms' Operation in Brazil, LAW.COM (Dec. 20, 2012), http://www.law.com/jsp/law/international/LawArticleIntl.jsp?id= $1202473434702 \&$ slreturn $=20130009194804$.

24. See Andrew Pugh, US Firms Line Up to Crack Brazil, THE LAWYER (July 5, 2010), http://www.thelawyer.com/us-firms-line-up-to-crack-brazil/1004933.article. 
the scrutiny placed on the partnerships between local and foreign law firms. 25

Within the last few years, U.S. law firms have begun to open offices in Brazil, particularly in Sao Paulo. ${ }^{26}$ The law firms that have attempted to move into Brazil are generally the largest, most elite U.S. law firms, and with them come the most resources. As Brazil has grown, so too has the complexity of the legal work within the country, so having law firms with some of the best educated lawyers and most resources may seem to be a blessing, but that is not how local authorities have viewed foreign firms attempting to enter the Brazilian market. The general feeling is actually the opposite. As a partner in a prominent Brazilian firm noted, foreign firms are "unfair competition."27

The tension between local and foreign-educated lawyers is exemplified by the actions of the $\mathrm{OAB}$ and local bar associations in Brazil. The OAB does not allow lawyers who are not educated in Brazil to be licensed to practice local law within Brazil. ${ }^{28}$ The only exception to this rule is if a lawyer is educated and licensed in Portugal, ${ }^{29}$ which stems from the historical ties between the two countries. However, there are relatively few lawyers in Portugal, ${ }^{30}$ so that exception is quite limited. As such, foreign-educated lawyers are relegated to acting as consultants, ${ }^{31}$ and even then must be granted approval from the OAB before they are allowed to do so. ${ }^{32}$ The requirements for approval are not overly difficult to obtain, ${ }^{33}$ but it still creates a barrier for foreign lawyers and restricts how they help Brazilian clients.

The $\mathrm{OAB}$ is not the only Brazilian bar association that has created barriers for foreign lawyers and law firms. In 2010, the Sao Paulo bar association ruled that formal associations between local and foreign law

25. Foreign Law Firms in Brazil: Keep Out, THE ECONOMIST (June 23, 2011), http://www.economist.com/node/18867851.

26. Brazil Nuts, supra note 22.

27. See Brian Baxter, Brazil Bar Concludes Foreign Law Firm Associations Break Rules, AMLAWDAILY.COM (Sept. 27, 2010), http:/amlawdaily.typepad.com/amlawdaily/ 2010/09/brazilforeignfirms.html.

28. Nathalie Leite Gazzaneo \& Ely Caetano Xavier Junior, How to Qualify as a Lawyer in Brazil, INTERNATIONAL BAR ASSOCIATION, http://www.ibanet.org/PPID/Constituent/ Student_Committee/qualify_lawyer_Brazil.aspx\#35 (last visited Apr. 3, 2014) (United Kingdom).

29. Id.

30. Number of Lawyers in CCBE Member Bars; Last Update: 2006, COUNCIL OF BARS AND LAW SOCIETIES OF EUROPE, http://www.ccbe.eu/fileadmin/user_upload/NTCdocument/ table_number_lawyers1_1179905628.pdf (last visited June 21, 2014) (Belgium).

31. See Machado, supra note 23.

32. Id.

33. Id. 
firms were against its rules and again affirmed this ruling in $2011 . .^{34}$ Because Sao Paulo is Brazil's largest city, and one of the largest in the world, this is a huge hindrance to foreign-educated lawyers in Brazil. While the OAB has not ruled on whether the decision of the Sao Paulo bar, association applies nationally, ${ }^{35}$ it does not really matter because of the size and influence of Sao Paulo. The inability of foreign law firms to create partnerships with local law firms in Sao Paulo would make it almost not worth law firms' resources to establish offices in Brazil.

Brazil has made strong efforts to limit the influence that foreigneducated lawyers and law firms have within the country. Despite its growing status as a world economic power and despite an influx of other professionals into Brazil, the legal community has thus far been antagonistic to such an influx of lawyers. As will be discussed later, this very likely is due to a desire to protect local lawyers. However, given the different approaches toward foreign-educated lawyers within the United States and how states most affected by globalization seem to be more liberal in their licensing rules, it is possible that further globalization and economic growth will put pressure on the $\mathrm{OAB}$ to relax its rules.

\section{India}

Like Brazil, India is one of the fastest growing economies in the world, and it also appears to have much the same attitude toward foreign-educated lawyers. ${ }^{36}$ In fact, foreign-educated lawyers are even more strongly regulated within India than in Brazil. ${ }^{37}$ While Brazil allows foreign law firms to set up offices within Brazil-although there is a question about whether foreign law firms can partner with local law firms-India does not even allow foreign law firms to establish offices within the country. ${ }^{38}$

India is primarily a common law country, due to the fact that it was part of the British Empire, and its 1950 Constitution incorporates British and U.S. common law. ${ }^{39}$ Despite this incorporation of the common law, India is utterly unreceptive to allowing even lawyers

34. Foreign Law Firms in Brazil: Keep Out, supra note 25.

35. Id.

36. Lawyers in India: Legally Barred, THE ECONOMIST (Apr. 24, 2008), http://www.economist.com/node/11090513; Dhananjay Mahapatra, Don't Let Foreign Law Firms In, THE TIMES OF INDIA, July 5, 2012, available at http:/timesofindia.indiatimes.com/ india/dontletforeignlawfirmsinsc/articleshow/14683330.cms.

37. $I d$.

38. See id.

39. Brief History of Law in India, THE BAR CouncIL OF INDIA, $\mathrm{http}: / / \mathrm{www} \cdot$ barcouncilofindia.org/about/about-the-legal-profession/legal-education-in-theunited-kingdom (last visited Oct. 15, 2012) (India). 
trained in other common law countries to practice within its borders. In fact, litigators, who do not have as much to fear in regards to losing business to foreign lawyers and law firms, may oppose foreign lawyers precisely due to India's colonial history. ${ }^{40}$ There is a sense that if foreign lawyers are allowed to come in and practice within India, it will lead to a form of pseudo-colonialism, ${ }^{41}$ leaving Indian lawyers to be treated as second class again. In addition to Indian litigators, business attorneys in India also strongly oppose allowing foreign lawyers to practice local law. ${ }^{42}$ As one of the fastest growing and largest economies in the world, Indiana presents great opportunity for business lawyers. Much like the business lawyers in Brazil, Indian business attorneys do not view foreign lawyers as tools to better serve their clients, but rather as competition. Therefore, they strongly favor the protectionist measures of the Law Society of India that forbid practice of Indian law by foreign lawyers. ${ }^{43}$

Despite the strong opposition to foreign lawyers by domestic lawyers in India, there has been a slight liberalizing of the strict measures against foreign lawyers in recent years. In 2012, the Chennai High Court held that, while it is still illegal for foreign lawyers and law firms to practice Indian law, they are allowed to come in to take part in international arbitration and advise on strictly foreign law. ${ }^{44}$ Though the court did affirm the strong protectionist measures against foreign lawyers and firms, the "fly in" rule appears to be a nod to the growing pressure of globalization. ${ }^{45}$ The ruling also allowed legal process outsourcing companies to be set up, but with the caveat that they are absolutely not allowed to give any legal advice. ${ }^{46}$ However positive this ruling may be for foreign lawyers, it is unclear whether there will be any further liberalizing of Indian rules due to the strong affirmation of the protectionist rules by the court.

Though India is a common law country, much like countries where most foreign-educated lawyers would come from, it has shown very few signs of embracing these foreign lawyers. While Brazil has strong protectionist measures, its rules seem to present foreign lawyers with an almost open door when compared to India's. India's protectionism

40. Lawyers in India, supra note 36.

41. Id.

42. $I d$.

43. Id.

44. Indian Court Upholds "Fly-in, Fly-out" Practice for Foreign Firms, THE LAWYER, (Feb. 21, 2012) http://www.thelawyer.com/indian-court-upholds-fly-in-fly-out-practice-forforeign-firms/1011514.article.

45. Id.

46. Id. 
appears to stem from different motives when compared to Brazil, 47 but both have the same desired effect-stemming the influence of globalization in the legal workforce.

\section{United Kingdom}

The United Kingdom has long been a global power, both through the British Empire and through its spheres of influence throughout the world. This would make it seem likely that the United Kingdom might be more welcoming of foreign lawyers and embrace globalization, as it is one of the reasons globalization exists in the first place. However, in recent years, in apparent pushback against British fears of too much immigration, the government has restricted foreign-educated lawyers coming from outside of the European Economic Area (EEA). ${ }^{48}$ This represents an attempt by yet another country to limit the increasing influence of globalization.

Beyond the recent actions taken by the government to prevent immigration of foreign-educated lawyers from outside of the EEA, the requirements to become a solicitor by the Law Society of England and Wales make it extremely difficult for a foreign-educated lawyer to practice English or Welsh law. To become a solicitor in the United Kingdom, a lawyer must obtain either a law degree or a Common Professional Examination/Graduate Diploma in Law. ${ }^{49}$ Following that, a prospective solicitor must take the Legal Practice Course and then complete a training contract, which generally lasts for two years. ${ }^{50}$ While this is the traditional route, lawyers who are educated and licensed outside of the United Kingdom may become a solicitor by taking the Qualified Lawyers Transfer Test. ${ }^{51}$ In addition to this test, the lawyer must have practiced for at least two years in a common law country and one of those years must have been spent practicing the law of England and Wales.52 This is difficult for many foreign-educated lawyers and again requires significant time input from the prospective solicitor. Although the United Kingdom is responsible for spreading the

47. Lawyers in India, supra note 36.

48. Natasha Gya Williams, UK Needs Its Foreign Lawyers, THE LAW SocIETY GAZETTE (Oct. 21, 2010), http://www.lawgazette.co.uk/opinion/comment/uk-needs-its-foreign-lawyers (United Kingdom).

49. Routes to Qualifying, THE LAW SOCIETY, http://www.lawsociety.org.uk/ careers/becoming-a-solicitor/routes-to-qualifying/ (last visited Dec. 17, 2012) (United Kingdom).

50. Id.

51. Qualified Lawyers Transfer Test, SOLICITORS REgULATION AUTHORITY, http://www.sra.org.uk/solicitors/qltt.page (last visited Dec. 17, 2012) (United Kingdom).

52. Id. 
common law throughout the world, it has also demonstrated that it would prefer to limit the domestic effects of globalization.

\section{E. Japan}

Japan represents a sort of middle ground between the extreme protectionist measures put in place in Brazil and India and a completely liberal legal practice scheme that would allow foreign-educated lawyers to freely practice domestic law. In recent years, the Japan Federal Bar Association (JFBA) enacted requirements for foreign-educated lawyers who wish to practice in Japan. ${ }^{33}$ Among these requirements is that the foreign lawyer must register with the JFBA. ${ }^{44}$ To register, however, the foreign lawyer must have at least three years of legal experience and two of those years must be outside of Japan..$^{55}$ This measure particularly hurt young foreign lawyers who were placed in Japanese offices when the economic downturn hit the United States. ${ }^{56}$ It is important to note that while this is protectionist, this is as extreme as the JFBA rules get, which pales in comparison to the measures enacted by the $\mathrm{OAB}$ and the Law Society of India.

Even more recently, there have been calls for Japan to further ease its already limited restrictions on foreign lawyers and law firms. While the three-year experience requirement is still in place, Japan recently ruled that foreign lawyers are allowed to incorporate in Japan. ${ }^{57}$ Previously, foreign lawyers were only allowed to open a single office. ${ }^{58}$ Now, however, foreign lawyers will be able to open multiple offices and act just as domestically trained Japanese lawyers do. ${ }^{59}$ This is stunning in comparison to the protectionist measures in place in other countries. The fact that foreign lawyers may practice just as domestic lawyers is a remarkable nod toward globalization. A comparison to the Indian "fly in" rule demonstrates the drastic differences between how these two countries handle foreign lawyers. The new Japanese rules also show how protectionist Brazil is being with its new rules that do not even allow foreign law firms to partner with local law firms. While it is unclear which approach will become more prevalent, Japan

53. Carolyn Elefant, Japan to Crack Down on Foreign Laywers, LAW.CoM (Feb. 10, 2009), http://legalblogwatch.typepad.com/legal_blog_watch/2009/02/japan-to-crack-downon-foreign-lawyers.html.

54. Id.

55. Id.

56. $I d$.

57. Jun Hongo, Calls Mount for Restrictions on Foreign Lawyers to be Eased, JAPAN TIMES (Mar. 8, 2012), http:/www.japantimes.co.jp/text/nn20120308a2.html (Japan).

58. Id.

59. Id. 
demonstrates that it is not necessary to limit foreign lawyers and still maintain a prominent place on the global stage.

\section{The DOWNSIDE To PROTECTION}

Protectionism is not in and of itself a bad thing. It is entirely reasonable for countries, or states within the United States, to want to protect and help their own citizens. It does, however, have negative effects that ultimately may outweigh the positives gained from protectionism. ${ }^{60}$ While protectionism appears to be the current trend in regards to foreign-educated lawyers, it remains unclear whether the measures put in place by countries such as Brazil and India are better than the more liberal approach taken by some states and Japan.

Protectionism is certainly not a concept that is unique to the legal world, so it is useful to take note of how protectionism has played out in other aspects of the economy. Perhaps the simplest form of economic protectionism occurs when a country imposes a trade tariff. A trade tariff will put an imported good at a price disadvantage as compared to local goods. ${ }^{61}$ While this may temporarily help the local producer, it results in a negative for the consumer because a good will artificially cost more than its free market price. The reduction in tariffs and increase in global trade helped fuel strong economic growth, particularly in the United States. ${ }^{62}$ However, as the economy hit the downturn, countries have increased protectionist measures, which ultimately hurt recovery. ${ }^{63}$ This increase in economic protectionism has coincided well with the increase in legal protectionism seen in Brazil, India, and the United Kingdom.

Another result of protectionist measures is the possibility of a trade war. A trade war exists when two or more countries all have tariffs or other protectionist measures in place against each other. ${ }^{64}$ While it does not appear that the primary motivation behind the actions of countries such as Brazil and India is due to a pseudo-trade war regarding the legal profession, if restrictions are continued and strengthened, a trade

60. See generally Doug Bandow, To Expand Commerce and Grow the Economy, Trade Freely with Europe, FoRBES (Jan. 7, 2012), http://www.forbes.com/sites/dougbandow/ 2013/01/07/to-expand-commerce-and-grow-the-economy-trade-freely-with-europe/; Murray N. Rothbard, Protectionism and the Destruction of Prosperity, LUDWIG VON MISES INSTITUTE (Dec. 20, 2012), http://mises.org/rothbard/protectionism.asp.

61. Tariffs, WORLD TRADE ORGANIZATION (Dec. 15, 2012), http://www.wto.org/english/ tratop_e/tariffs_e/tariffs_e.htm (Switzerland).

62. See Bandow, supra note 62.

63. Id.

64. Trade War, Center For Progressive Economics (June 1, 2011), http://cpe.us.com/346/trade-war/. 
war could certainly exist. The United States is home to many of the largest and most sophisticated law firms in the world; 65 this means that restrictions on foreign lawyers and law firms disproportionately affect U.S. lawyers. While some U.S. states are currently open to foreigneducated lawyers, if more countries restrict the movement of U.S. lawyers, these states may restrict foreign-educated lawyers as a means of retaliation, which is often how countries react to the imposition of trade barriers.

Beyond the hypothetical possibility of a pseudo-trade war amongst countries regarding lawyers, the restriction of foreign lawyers and law firms has very real effects on the type of counsel that may be offered to clients. Many of the largest, and thus most resourceful, law firms are based out of the United States and the United Kingdom. ${ }^{66}$ While simply being large does not necessarily equate to providing the best legal service, these giant firms are staffed with more lawyers than smaller firms, and this allows them to have more lawyers that specialize in a wider range of law. The ability to have specialists who address a client's issues means that a client can receive more pointed and direct counsel. Also, since large law firms have specialists in just about every area of corporate law, clients may simply use one law firm to address the many issues that arise in the modern business world.

The scope of the counsel that may be provided to clients is not the only thing that is negatively affected by the imposition of restrictions on foreign lawyers. The quality of the counsel provided those clients is also negatively affected. By no means an exact science, global law school rankings provide a rough estimate of the quality of legal education. Law schools located in the United States and the United Kingdom dominate these rankings. ${ }^{67}$ This is not a statement that only quality counsel comes from lawyers educated at those schools. Rather, explicitly limiting the possibility of receiving counsel from lawyers educated at these schools, as is the case in Brazil because there no globally high ranking Brazilian law schools, reduces the options that local clients have. Because competition results in higher quality, limiting options negatively affects those in need of legal services.

Brazil, in particular, appears to be cutting off its nose to spite its face. Brazil has an extremely high number of law schools; in fact, it has

65. See David Lat, Biggest Law Firms in the World: Meet the Global 100, ABOvE THE LAW (Sept. 29, 2011), http://abovethelaw.com/2011/09/the-biggest-law-firms-in-the-worldmeet-the-global-100\%.

66. Id.

67. See Vivia Chen, Law School Rankings-International Edition, THECAREERIST.COM (Mar. 7, 2012), http://thecareerist.typepad.com/thecareerist/2012/03/law-school-ranking. the-international-edition.html. 
more law schools than the rest of the world combined.68 The quality of education is reflected in the fact that a very small number of law graduates are actually able to pass the bar exam in Brazil.69 But this also means that there are a huge number of law graduates, and the $\mathrm{OAB}$ seems to be protecting these large numbers through its restrictions on foreign lawyers. The problem of too many law graduates in Brazil is also demonstrated by the fact that recently an eight year old was able to pass the law school entrance exam. ${ }^{70}$ While the existence of a prodigy certainly is a possibility, it is more likely that the exam is too easy, and this means that many unqualified people attend law school in Brazil.71 Ultimately, the combination of restrictions on foreign lawyers and the quality of legal education in Brazil means that clients will suffer with an inferior quality of counsel.

On the surface, restricting foreign lawyers may appear reasonable. After all, a lawyer educated within a particular jurisdiction will presumably be more familiar with that jurisdiction's law and thus in a better position to counsel regarding that law. However, there are clear disadvantages that exist when countries put extreme restrictions on the practice of foreign lawyers. They risk creating a pseudo-trade war with other countries. Also, while the restrictions certainly help domestic lawyers through limiting competition, this limitation most likely hurts clients. Clients are unable to tap into the resources that the world's largest law firms have access to and are restricted from accessing lawyers that are educated at some of the world's most elite law schools. Again, this does not mean that clients will necessarily be given poor counsel, but it can create unnecessary hindrances for the growing economies of countries like India and Brazil.

\section{A BETTER WAY FORWARD}

As Japan has demonstrated with its fairly sensible rules regarding foreign lawyers, it is not necessary for a country to impose strict protectionist measures regarding the legal profession. Japan has been

68. The Brazilian Legal Profession, HARVARD LAW SCHOOL (Oct. 5, 2012), http://www.law.harvard.edu/programs/plp/pdf/Brazilian_Legal_Profession.pdf.

69. See Priscilla Borges, Um Terço das 30 Piores Instituiçôes na OAB Tem Boa Nota Pelo MEC, ULTIMO SEGUNDO (Sept. 27, 2011), http://ultimosegundo.ig.com.br/educacao/ um-terco-das-30-piores-instituicoes-na-oab-tem-boa-nota-pelo-mec/n1597244913925.html (Brazil); see also The Brazilian Legal Profession, supra note 70 (noting that only an undergraduate law degree is required to practice law in Brazil and most students complete a total of five years of secondary education prior to sitting for the $\mathrm{OAB}$ ).

70. Tales Azzoni, Brazilian Boy, 8, Passes Law School Entrance Exam, THE GUARDIAN (Mar. 6, 2008), http://www.guardian.co.uk/world/2008/mar/07/brazil (United Kingdom).

71. See $i d$. 
well ahead of many countries in liberalizing its rules regarding the practice of foreign lawyers. In 1986, Japan began to loosen its strong restrictions on foreign lawyers when it passed the Foreign Lawyers Law. ${ }^{72}$ Though Japan was open to foreign lawyers for a period of roughly ten years following World War II, it imposed strict restrictions of those lawyers in 1955 that remained in place until $1986 .{ }^{73}$ However, as Japan grew as an economy, it recognized the need to open up its rules regarding foreign lawyers and enacted the Foreign Lawyers Law in 1986. The first iteration of the law demonstrates an anti-trade war mentality because it requires the home country of a foreign lawyer wishing to be registered in Japan to allow similar registration for Japanese lawyers. ${ }^{74}$ This is precisely the kind of rule that allows a country to ease its way into liberalization and would be ideal for India. India has a few elite law schools, so other countries could see Indian lawyers as a desirable commodity .If a country requires a foreign lawyer's home country to allow its lawyers to practice local law, that helps ease the concerns over domestic lawyers losing jobs. A domestic lawyer would then have an opportunity to seek a job as a foreign lawyer in another country.

The progression of Japan's attitude toward foreign lawyers represents an ideal manner of liberalization that developing countries currently using protectionist measures could employ, though preferably on a shorter timescale. When the Foreign Lawyers Law was first enacted, foreign lawyers were still not allowed to practice Japanese law, and foreign law firms could not employ Japanese lawyers. ${ }^{75}$ However, that slowly began to change, particularly due to pressure from the United States and Australia. ${ }^{76}$ By 1994, amendments had been passed that eased the experience and reciprocity requirements for foreign lawyers to be registered in Japan. ${ }^{77}$ Foreign lawyers are now free to practice Japanese law, and foreign law firms can incorporate and have multiple offices throughout Japan. The experience requirement still exists, which demonstrates that it is not necessary for a country to completely abandon all protectionist measures in regards to regulation of the legal profession.

72. Kristina Bodil De Vere Stevens, Note, Liberalisation of the Laws Governing Foreign Lawyers in Japan: Commentary on the Developments between 1984 and 1994, 4 ASIA PAC. L. REV. 49, 54-55 (1995).

73. Id. at $51-54$.

74. Id. at 55 .

75. $I d$.

76. See id. at 59-60.

77. Id. at 60 . 
Beyond reciprocity and gradual liberalization, countries may find that a functional equivalency exam will allow it to protect domestic lawyers from a huge influx of foreign lawyers, but also provide opportunities for well-qualified foreign lawyers to practice. This would be similar to the examination that is required for foreign lawyers in the United Kingdom, though a more liberal approach toward granting the examination would be ideal. Allowing foreign lawyers who are well versed in local law to practice, even though they were not educated in that jurisdiction, will provide clients with access to sufficient competition regarding legal services. Ultimately, though, it appears that some of the fastest growing economies in the world have decided it is better to shield themselves from the influence of foreign lawyers and law firms. Hopefully they learn from Japan and embrace globalization in the legal profession.

\section{CONCLUSION}

Globalization is an inevitable part of professional life. Countries throughout the world experience foreign professionals moving to work away from their home country. Globalization's forces affect the legal market, much like they affect the market for other professionals such as doctors, ${ }^{78}$ but some bar associations have taken severe measures to blunt the influence of foreign lawyers. Because the number of students obtaining tertiary education has greatly increased recently, it is inevitable that the total number of lawyers will also increase. As opposed to embracing this increased pool of possible lawyers, many places have chosen to protect their domestic lawyers at the expense of foreign lawyers.

There are varying approaches to regulating foreign lawyers. Some places, such as India and Brazil, have strict restrictions that make it exceedingly difficult for a foreign lawyer to practice any kind of law in their jurisdiction. India has had these strong protectionist measures in place for many years, partially due to its experience as a colony of the British Empire, and has feared the overwhelming influence of foreign lawyers if those lawyers were allowed to practice Indian law. ${ }^{79}$ Brazil, on the other hand, has moved to become even more protectionist in recent years with the Sao Paulo bar association's ban on partnership between foreign and local law firms. ${ }^{80}$

78. See McAllester, supra note 2.

79. See Lawyers in India, supra note 36.

80. See id. 
Even the United States, one of the leading forces in globalization, is not entirely on board with the liberalization of rules regarding foreign lawyers. Many states will not allow a foreign lawyer to be directly licensed in their jurisdiction by taking the local bar exam because they require a law degree from an $\mathrm{ABA}$ accredited law school to sit for the bar. ${ }^{81}$ Most of these states, however, do allow foreign lawyers to become registered through reciprocity. However, only five states allow direct registration of foreign lawyers, so the opportunities for foreign lawyers are limited. The jurisdictions that allow direct registration represent parts of the United States that are likely the most globally important, for instance California and New York. This could be a good sign that as countries become greater players on the global stage, they may liberalize their rules regarding foreign lawyers.

Japan has embraced globalization of the legal profession perhaps more than any other country. Despite having protectionist measures in place for a period of time following World War II, Japan recognized the importance of allowing foreign lawyers to practice, not only for relations with other countries, but also to better serve local Japanese businesses. The liberalization of Japan's laws occurred over a number of years. Its Foreign Lawyers Law now allows registered foreign lawyers to practice Japanese law, in stark contrast to Brazil and India's treatment of foreign lawyers.

Japan represents a model that India and Brazil could use to liberalize their current rules. Liberalization is important so that these countries can avoid the negatives that accompany protectionism. Not only will continued protectionist measures hurt relationships with other countries, as trade barriers often do, but they are also a disservice to domestic businesses. These measures prevent local businesses from hiring some of the largest, most resourceful law firms in the world. Given that businesses need ever more sophisticated legal counsel as they expand globally, soon these protectionist measures will most likely cause more harm than good. While protectionism may have served a purpose, it is time for these growing economic powers to open their legal profession to positive aspects of globalization.

81. Taking the Bar as a Foreign Lawyer, supra note 6. 